\title{
Hipoalbuminemia prabedah sebagai faktor prognostik enterokolitis pascabedah penderita megakolon kongenital (Hirschsprung's disease)
}

\author{
Preoperative hypoalbuminemia as a prognostic factor of postoperative enterocolitis in congenital megacolon \\ (Hirschsprung's disease) patients
}

Rochadi $^{1}$

\begin{abstract}
Background: Hirschsprung's disease or congenital megacolon is the congenital absence of ganglion cells in the colon. The rectum is always involved and in $90 \%$ of patients the abnormality is confined to the rectum and sigmoid. Absence of ganglion cells prevents peristalsis, resulting in functional obstruction. The success of Hirschsprung's treatment depends on many factors such as age at the time of operation, body weight, hemoglobin levels, albumin levels, length of operation, length of stay and other prognostic factors. Post operative enterocolitis and other complications still represent as the problem wich often are faced by pediatric surgeons.

Objective: The aim of this study was to evaluate the effect of albumin levels on postoperative enterocolitis in children presenting with congenital megacolon.

Method: We conducted an ambidirectional cohort study involving children presenting with Hirschsprung's disease in Dr. Sardjito, Panti Rapih and Permata Husada hospitals in Yogyakarta city from January 2005 to December 2010. All children had been operated using ERPT and PSNRHD methods. The subjects were classified into normoalbuminemia $(>3.5 \mathrm{~g} / \mathrm{dl})$ and hypoalbuminemia $(\leq 3.5 \mathrm{~g} / \mathrm{dl})$. The effect of albumin levels on postoperative enterocolitis were indicated by relative risk and $95 \%$ confidence interval.

Results: Out of 104 children with Hirschsprung's disease, 53 (51\%) were hypoalbuminemic and 51 (49\%) were normoalbuminemia. Postoperative enterocolitis was found in $18(17.3 \%)$ children, 11/18 (61.1\%) of them were hypoalbuminemia, whereas $7 / 18$ (38.9\%) were normoalbuminemia. Albumin levels were not significant prognostic factor for postoperative enterocolitis in children with congenital megacolon (RR=1.51; 95\% Cl:0.64-3.60; $p=0.34$ ).

Conclusion: The albumin levels are not prognostic factor for postoperative enterocolitis in children with congenital megacolon.
\end{abstract}

KEY WORDS: postoperative enterocolitis, preoperative albumin level, congenital megacolon

\begin{abstract}
ABSTRAK
Latar belakang: Penyakit Hirschsprung atau megakolon kongenital adalah kelainan kongenital berupa ketiadaan sel ganglion pada kolon. Rektum selalu terlibat dan $90 \%$ kelainan ini didapatkan pada rektum dan sigmoid. Ketiadaan sel ganglion akan menyebabkan gangguan peristaltik sehingga mengakibatkan terjadinya ileus fungsional. Keberhasilan terapi tergantung pada beberapa faktor antara lain umur saat operasi, berat badan, kadar hemoglobin, albumin, lama operasi, lama perawatan, dan faktor-faktor prognostik lainnya. Enterokolitis dan komplikasi pascabedah lainnya masih merupakan masalah yang harus dihadapi oleh para ahli bedah anak.

Tujuan: Menilai pengaruh kadar albumin prabedah terhadap kejadian enterokolitis pascabedah pada penderita penyakit megakolon kongenital.

Metode: Penelitian dilakukan dengan desain kohort ambidireksional pada anak dengan penyakit Hirschsprung yang dilakukan operasi dengan metode ERPT dan PSNRHD di RSUP Dr. Sardjito, RS Panti Rapih, dan RS Permata Husada Yogyakarta. Kadar albumin dibedakan menjadi normoalbuminemia (>3,5 g/dl) dan hipoalbuminemia ( $\leq 3,5 \mathrm{~g} / \mathrm{dl})$. Kadar albumin prabedah sebagai faktor prognostik enterokolitis pascabedah dinyatakan dengan RR dan IK $95 \%$.

Hasil: Dari 104 anak dengan penyakit Hirschsprung, diperoleh 53 (51\%) anak dengan hipoalbuminemia dan 51 (49\%) anak dengan normoalbuminemia. Enterokolitis pascabedah terjadi pada 18 (17,3\%) anak, diantaranya terdapat 11 (61,1\%) anak dengan hipoalbuminemia dan 7 (38,9\%) anak dengan normoalbuminemia. Kadar albumin bukan merupakan faktor prognostik enterokolitis pascabedah pada anak megakolon kongenital (RR=1,51; IK 95\%:0,64-3,60; $p=0,34)$.

Simpulan: Kadar albumin bukan merupakan faktor prognostik enterokolitis pascabedah pada anak dengan megakolon kongenital.
\end{abstract}

KATA KUNCI: enterokolitis pascabedah, kadar albumin prabedah, penyakit megakolon kongenital

\footnotetext{
${ }^{1}$ Korespondensi: Bagian Bedah Anak, Rumah Sakit Umum Pusat Dr. Sardjito, Jl. Kesehatan No 1, Yogyakarta 55281, Telp (0274) 631036
} 


\section{PENDAHULUAN}

Penyakit Hirschsprung adalah kelainan kongenital pada kolon yang ditandai dengan tidak adanya sel ganglion parasimpatis pada pleksus submukosus Meissneri dan pleksus mienterikus Auerbachi. Penyakit ini disebabkan oleh terhentinya migrasi kraniokaudal sel krista neuralis di daerah kolon distal pada minggu kelima sampai minggu keduabelas kehamilan untuk membentuk sistem saraf intestinal dan sembilan puluh persen terjadi pada rektum dan sigmoid (1).

Insiden penyakit Hirschsprung adalah 1 dalam 5000 kelahiran hidup sehingga di Indonesia diperkirakan akan lahir 1200 bayi dengan penyakit Hirschsprung setiap tahunnya dan rasio laki-laki dibanding perempuan adalah 4:1 (2). Diagnosis penyakit Hirschsprung harus dapat ditegakkan sedini mungkin karena berbagai komplikasi yang dapat terjadi akan sangat membahayakan pasien seperti terjadinya konstipasi, enterokolitis, perforasi usus serta sepsis yang dapat menyebabkan kematian (3).

Enterokolitis merupakan penyebab utama mortalitas dan morbiditas pada penderita penyakit Hirschsprung (4). Hasil penelitian di Amerika Serikat menunjukkan terjadinya enterokolitis pascabedah sebesar $53 \%$ (5) dan penelitian lain melaporkan terjadinya enterokolitis pascabedah sebesar $61,9 \%$ dari kasus-kasus penyakit megakolon yang telah dioperasi (6). Penelitian yang dilakukan di Irlandia menunjukkan angka kejadian enterokolitis sebesar $30 \%$ pada 135 pasien pascabedah dengan faktor risiko umur, jenis kelamin, dan jenis tindakan bedah yang dilakukan (7). Penelitian di Skotlandia menyimpulkan bahwa penyebab tejadinya enterokolitis pascabedah adalah multifaktor yaitu adanya bakteri, dilatasi kolon yang mengakibatkan iskemia, kelainan mukosubstan kolon, kenaikan aktivitas prostaglandin E1, dan kelainan imunologis (8).

Albumin merupakan protein utama dalam plasma manusia dan penyusun sekitar $60 \%$ dari protein plasma total. Albumin manusia terdiri atas satu rantai polipeptida yang tersusun atas 585 asam amino dan mengandung 17 buah ikatan disulfida. Albumin mempunyai bentuk elips, yang berarti protein ini tidak akan banyak meningkatkan viskositas plasma seperti halnya fibrinogen. Berat molekul yang relatif rendah dan konsentrasinya yang tinggi, maka albumin diperkirakan bertanggung jawab atas $75-80 \%$ dari tekanan osmotik plasma manusia dan menentukan distribusi cairan antara darah dan jaringan. Selain itu, albumin juga berfungsi sebagai penyedia berbagai asam amino untuk membentuk protein lain, transportasi berbagai protein, dan dapat mengikat berbagai macam ligan seperti asam lemak bebas, steroid, dan bilirubin. Depresi albumin karena gangguan sintesis seperti pada malnutrisi, malabsorbsi atau kehilangan yang terlalu banyak akan menyebabkan terjadinya ketidakseimbangan tekanan onkotik intravaskuler yang berbahaya. Pemberian albumin akan memperbaiki volume plasma secara efektif sehingga akan membantu resusitasi pada penderita peritonitis maupun enterokolitis (9). Peranan albumin sebagai metabolic compensator akan mempengaruhi terjadinya komplikasi pascabedah seperti terjadinya enterokolitis maupun efek samping yang tidak diinginkan pada setiap tindakan bedah (10) sehingga perlu adanya penelitian yang menilai pengaruh kadar albumin terhadap terjadinya enterokolitis pascabedah pada penderita megakolon kongenital.

\section{BAHAN DAN METODE}

Penelitian ini dilakukan di Bagian Bedah RSUP Dr. Sardjito Yogyakarta, RS Panti Rapih Yogyakarta, dan RS Permata Husada Yogyakarta dengan desain ambidirectional cohort yang merupakan gabungan desain kohort prospektif dan desain kohort retrospektif dengan lama waktu pengamatan 6 bulan pascabedah. Penelitian dilaksanakan pada bulan Januari 2005 sampai Desember 2010. Populasi penelitian ini adalah anak dengan megakolon kongenital (Hirschsprung's disease) yang dilakukan operasi dengan metode endorectal pullthrough (ERPT) dan posterior sagittal neurectomy repair for Hirschsprung's disease (PSNRHD). Perhitungan besar sampel dihitung berdasar rumus untuk penelitian kohort dengan uji hipotesis terhadap risiko relatif (11) dengan tingkat kemaknaan $(\alpha)$ sebesar 0,$05 ; p_{1}$ adalah proporsi efek pada kelompok ERPT; $\mathrm{p}_{2}$ adalah proporsi efek pada kelompok PSNRHD; kesalahan tipe II (B) sebesar 0,20; dan power $\left(Z_{1-\beta}\right)$ sebesar $80 \%$ mendapatkan besar sampel pada setiap kelompok sebanyak 45 subjek penelitian sehingga keseluruhan jumlah subjek adalah 90 orang.

Kriteria inklusi subjek penelitian ini adalah subjek berumur kurang atau sama dengan 14 tahun, bersedia mengikuti penelitian atas persetujuan orang tua dengan menandatangani informed concent, dan menjalani terapi lengkap sampai waktu follow-up. Kriteria eksklusi adalah adanya kelainan gastrointestinal lain yang akan mengganggu jalannya operasi, megakolon residif, serta adanya kelainan fungsi hati dan jantung yang akan membahayakan penderita apabila dikerjakan tindakan operasi. Sampel penelitian yang diikutkan dalam penelitian ini sejumlah 104 penderita penyakit Hirschsprung pascabedah yang memenuhi kriteria inklusi dan tidak memenuhi kriteria eksklusi. Penelitian ini sudah mendapatkan kelaikan etik dari Komisi Etik Penelitian Kedokteran dan Kesehatan Fakultas Kedokteran Universitas Gadjah Mada.

Luaran penelitian ini adalah kejadian enterokolitis pascabedah yang ditandai dengan adanya distensi abdomen, demam, dan diare sedangkan faktor prognostik yang diuji adalah status gizi berdasarkan kadar albumin serum dengan nilai lebih dari atau sama dengan $3,5 \mathrm{~g} / \mathrm{dl}$ sebagai normoalbumin dan kurang dari $3,5 \mathrm{~g} / \mathrm{dl}$ sebagai hipoalbumin (12). Faktor-faktor prognostik lainnya adalah 
jenis kelamin, umur saat operasi, berat badan yang diukur pada saat masuk rumah sakit oleh perawat dan dokter residen, kadar hemoglobin $(\mathrm{Hb})$ diukur sebelum tindakan operasi yang dilakukan di laboratorium rumah sakit setempat, lama operasi diukur sejak irisan pertama dimulai sampai menutup kulit, dan lama perawatan yang diukur sejak hari operasi sampai penderita diperbolehkan berobat jalan. Diagnosis megakolon kongenital ditentukan berdasarkan pemeriksaan klinis dan radiologis yang dikonfirmasi dengan pemeriksaan patologi anatomi sedangkan teknik operasi ditentukan oleh penulis dengan persetujuan keluarga.

Kadar albumin serum diperoleh dari catatan medis pasien yang diambil dari hasil pemeriksaan laboratorium rumah sakit setempat sebelum dilakukan tindakan operasi sedangkan data berat badan diperoleh dari penimbangan saat pasien masuk rumah sakit. Evaluasi pada subjek penelitian dilakukan dengan cara pemeriksaan pada waktu penderita kontrol di poliklinik, kunjungan rumah atau melalui surat maupun telepon.

Berat badan subjek penelitian dibedakan menjadi dua berdasarkan kategori pembedahan yaitu kurang dari atau sama dengan $12 \mathrm{~kg}$ dan lebih dari $12 \mathrm{~kg}$ sesuai dengan sumber yang menyatakan bahwa untuk melakukan tindakan pembedahan pada penderita dengan megakolon kongenital adalah berat badan di atas $10 \mathrm{~kg}$. Hal tersebut dengan pertimbangan bahwa harus dilakukan perbaikan keadaan umum yang optimal dahulu sebelum dilakukan tindakan bedah, sebagai akibat adanya obstruksi usus fungsional yang dialami penderita megakolon kongenital (13-15). Kadar $\mathrm{Hb}$ subjek penelitian dibedakan menjadi dua kategori yaitu kurang dari atau sama dengan $12 \mathrm{~g} / \mathrm{dl}$ dan lebih dari $12 \mathrm{~g} / \mathrm{dl}$ sesuai dengan syarat anestesi untuk operasi neonatus, bayi, dan anak yaitu kadar $\mathrm{Hb}=12 \mathrm{~g} /$ dl. Keadaan tersebut diperlukan untuk menjaga derajat keamanan anestesi sehubungan dengan oksigenasi jaringan serta untuk mencegah terjadinya asidosis selama pembedahan. Hal ini didukung oleh sumber yang menyatakan bahwa untuk menjaga keamanan anestesi, kadar $\mathrm{Hb}$ yang diperlukan untuk operasi pada anak-anak adalah $11,4 \pm 1,8 \mathrm{~g} / \mathrm{dl}$ (16). Kriteria umur penderita kurang dari atau sama dengan 14 tahun sesuai dengan protokol pembedahan pada neonatus, bayi, dan anak (17).

Penyakit megakolon kongenital pada penelitian ini adalah tipe 'short segmen' dengan batas ketinggian segmen yang aganglionik berada di bawah kolon rektosigmoid yang ditentukan dengan pemeriksaan radiologi. Enterokolitis pascabedah adalah infeksi pada usus dengan tandatanda diare hebat, kembung, dan demam yang terjadi setelah tindakan bedah. Analisis bivariat dilakukan untuk menghitung relative risk (RR) dengan interval kepercayaan $95 \%$. Analisis multivariat menggunakan uji regresi logistik ganda dengan memasukkan faktor-faktor prognostik yang mempunyai nilai $p$ kurang dari 0,25 pada uji bivariat.
HASIL

Tabel 1. Karakteristik dasar subjek penelitian

\begin{tabular}{|c|c|c|c|c|}
\hline \multirow{3}{*}{ Variabel } & \multicolumn{4}{|c|}{ Enterokolitis pascabedah } \\
\hline & \multicolumn{2}{|c|}{ Enterokolitis } & \multicolumn{2}{|c|}{ Tidak enterokolitis } \\
\hline & $\mathbf{n}$ & $\%$ & $\mathbf{n}$ & $\%$ \\
\hline \multicolumn{5}{|l|}{ Jenis kelamin } \\
\hline Laki-laki & 13 & 72,2 & 53 & 61,6 \\
\hline Perempuan & 5 & 27,8 & 33 & 38,4 \\
\hline \multicolumn{5}{|c|}{ Umur operasi (bulan) } \\
\hline$\leq 12$ & 7 & 38,9 & 41 & 47,7 \\
\hline$>12$ & 11 & 61,1 & 45 & 52,3 \\
\hline \multicolumn{5}{|c|}{ Berat badan (kg) } \\
\hline$\leq 12$ & 13 & 72,2 & 58 & 67,4 \\
\hline$>12$ & 5 & 27,8 & 28 & 32,6 \\
\hline \multicolumn{5}{|l|}{ Kadar $\mathrm{Hb}(\mathrm{g} / \mathrm{dl})$} \\
\hline$\leq 12$ & 7 & 38,9 & 30 & 34,9 \\
\hline$>12$ & 11 & 61,1 & 56 & 65,1 \\
\hline
\end{tabular}

Tabel 1 menunjukkan bahwa proporsi kejadian enterokolitis pascabedah pada laki-laki 2,6 kali lebih besar dibandingkan perempuan. Umur pada saat dilakukan operasi berkisar antara 1-115 bulan dengan rerata umur $26,72 \pm 29,57$ bulan. Berat badan terendah 2,4 $\mathrm{kg}$ dan tertinggi $40 \mathrm{~kg}$ dengan rerata 10,84 $\pm 7,38 \mathrm{~kg}$. Kadar $\mathrm{Hb}$ terendah $10,10 \mathrm{~g} / \mathrm{dl}$ dan tertinggi $19,7 \mathrm{~g} / \mathrm{dl}$ dengan rerata $12,81 \pm 1,59 \mathrm{~g} / \mathrm{dl}$.

Pada penelitian ini, kadar albumin subjek penelitian yang tergolong hipoalbumin lebih banyak (51\%) dibandingkan yang normoalbumin $(49 \%)$ dengan kadar terendah $2,5 \mathrm{~g} / \mathrm{dl}$ dan tertinggi $5,40 \mathrm{~g} / \mathrm{dl}$ serta rerata 3,63 $\pm 0,52 \mathrm{~g} / \mathrm{dl}$. Kejadian enterokolitis pada subjek dengan hipoalbumin adalah 1,51 kali lebih besar dibandingkan subjek dengan normoalbumin tetapi tidak bermakna $(R R=1,51 ; 95 \% \mathrm{Cl}: 0,64-3,60 ; p=0,344)$. Lama waktu yang diperlukan untuk operasi dihitung mulai dari irisan pertama sampai menutup kulit kembali yaitu diperoleh waktu operasi tercepat 15 menit dan terlama 300 menit. Kejadian enterokolitis pascabedah pada pasien dengan lama operasi kurang dari atau sama dengan 60 menit adalah 0,22 kali lebih besar dibandingkan dengan lama operasi lebih dari 60 menit dan hasil tersebut menunjukkan perbedaan yang bermakna $(\mathrm{RR}=0,22 ; 95 \% \mathrm{Cl}: 0,08-0,62 ; \mathrm{p}=0,001)$. Lama waktu perawatan di rumah sakit yang tersingkat adalah 5 hari dan terlama 60 hari dengan rerata 13,94 $\pm 7,80$ hari. Kejadian enterokolitis pada lama perawatan kurang dari atau sama dengan 10 hari adalah 0,26 kali lebih besar dibandingkan dengan lama perawatan lebih dari 10 hari dan hasil tersebut menunjukkan perbedaan yang bermakna $(R R=0,26 ; 95 \% \mathrm{Cl}: 0,06-1,06 ; p=0,032)$ (Tabel 2).

Enterokolitis pascabedah terjadi pada 18 subjek $(17,3 \%)$ dengan perincian metoda ERPT dilakukan pada 14 subjek $(31,1 \%)$ dan PSNRHD pada 4 subjek $(6,8 \%)$. Kejadian enterokolitis pascabedah dengan menggunakan 
Tabel 2. Analisis bivariat albumin dan variabel lain berdasarkan enterokolitis pascabedah

\begin{tabular}{|c|c|c|c|c|c|c|c|c|}
\hline \multirow{3}{*}{ Variabel } & \multicolumn{4}{|c|}{ Enterokolitis pascabedah } & \multirow{2}{*}{\multicolumn{2}{|c|}{ Total }} & \multirow{3}{*}{ RR (95\% Cl) } & \multirow{3}{*}{$\mathbf{p}$} \\
\hline & \multicolumn{2}{|c|}{ Ya } & \multicolumn{2}{|c|}{ Tidak } & & & & \\
\hline & $\mathrm{n}$ & $\%$ & $\mathbf{n}$ & $\%$ & $\mathbf{n}$ & $\%$ & & \\
\hline \multicolumn{9}{|c|}{ Umur operasi (bulan) } \\
\hline$\leq 12$ & 7 & 38,9 & 41 & 47,7 & 48 & 46,2 & $0,74(0,31-1,76)$ & 0,497 \\
\hline$>12$ & 11 & 61,1 & 45 & 52,3 & 56 & 53,8 & 1 & \\
\hline \multicolumn{9}{|l|}{ Berat badan (kg) } \\
\hline$\leq 12$ & 13 & 72,2 & 58 & 67,4 & 71 & 68,3 & $1,21(0,47-3,11)$ & 0,692 \\
\hline$>12$ & 5 & 27,8 & 28 & 32,6 & 33 & 31,7 & 1 & \\
\hline \multicolumn{9}{|l|}{ Jenis kelamin } \\
\hline Laki-laki & 13 & 72,2 & 53 & 61,6 & 66 & 63,5 & $1,50(0,58-3,88)$ & 0,396 \\
\hline Perempuan & 5 & 27,8 & 33 & 38,4 & 38 & 36,5 & 1 & \\
\hline \multicolumn{9}{|c|}{ Kadar hemoglobin (g/dl) } \\
\hline$\leq 12$ & 7 & 38,9 & 30 & 34,9 & 37 & 35,6 & $1,15(0,49-2,72)$ & 0,747 \\
\hline$>12$ & 11 & 61,1 & 56 & 65,1 & 67 & 64,4 & 1 & \\
\hline \multicolumn{9}{|c|}{ Kadar albumin (g/dl) } \\
\hline$\leq 3,5$ & 11 & 61,1 & 42 & 48,8 & 53 & 51,0 & $1,51(0,64-3,60)$ & 0,344 \\
\hline$>3,5$ & 7 & 38,9 & 44 & 51,2 & 51 & 49,0 & 1 & \\
\hline \multicolumn{9}{|c|}{ Lama operasi (menit) } \\
\hline$\leq 60$ & 4 & 22,2 & 55 & 64,0 & 59 & 56,7 & $0,22(0,08-0,62)$ & $0,001^{*}$ \\
\hline$>60$ & 14 & 77,8 & 31 & 36,0 & 45 & 43,3 & 1 & \\
\hline \multicolumn{9}{|c|}{ Lama perawatan (hari) } \\
\hline$\leq 10$ & 2 & 11,1 & 32 & 37,2 & 34 & 32,7 & $0,26(0,06-1,06)$ & $0,032^{*}$ \\
\hline$>10$ & 16 & 88,9 & 54 & 62,8 & 70 & 67,3 & 1 & \\
\hline \multicolumn{9}{|l|}{ Jenis operasi } \\
\hline PSNRHD & 4 & 22,2 & 55 & 64,0 & 59 & 56,7 & $0,22(0,08-0,62)$ & $0,001^{*}$ \\
\hline ERPT & 14 & 77,8 & 31 & 36,0 & 45 & 43,3 & 1 & \\
\hline
\end{tabular}

Keterangan: * ${ }^{*}$ bermakna $(p<0,05)$

Tabel 3. Analisis multivariat regresi logistik pengaruh albumin dan faktor prognostik lain terhadap enterokolitis pascabedah

\begin{tabular}{|c|c|c|c|c|c|c|}
\hline \multirow{2}{*}{ Variabel } & \multicolumn{2}{|c|}{ Enterokolitis pasca bedah } & \multirow{2}{*}{$\begin{array}{l}\text { Total } \\
\mathrm{n}(\%)\end{array}$} & \multirow{2}{*}{$\beta$} & \multirow{2}{*}{$\mathbf{p}$} & \multirow{2}{*}{$\operatorname{RR}(95 \% \mathrm{CI})$} \\
\hline & $\mathrm{Ya}(\mathrm{n}, \%)$ & Tidak (n, \%) & & & & \\
\hline \multicolumn{7}{|c|}{ Lama operasi (menit) } \\
\hline$\leq 60$ & $4(22,2)$ & $55(64,0)$ & $59(56,7)$ & 1,76 & 0,030 & $5,79(1,15-29,16)$ \\
\hline$>60$ & $14(77,8)$ & $31(36,0)$ & $45(43,3)$ & & & \\
\hline \multicolumn{7}{|c|}{ Lama perawatan (hari) } \\
\hline$\leq 10$ & $2(11,1)$ & $32(37,2)$ & $34(32,7)$ & 0,548 & 0,580 & $1,73(0,25-12,04)$ \\
\hline$>10$ & $16(88,9)$ & $54(62,8)$ & $70(67,3)$ & & & \\
\hline
\end{tabular}

teknik PSNRHD 0,22 kali lebih besar dibandingkan dengan teknik ERPT dan hasil tersebut menunjukkan perbedaan yang bermakna $(R R=0,22 ; 95 \% \mathrm{Cl}: 0,08-0,62 ; p=0,001)$ (Tabel 2). Dengan demikian, dapat disimpulkan bahwa jenis kelamin, umur operasi, berat badan, kadar $\mathrm{Hb}$, dan kadar albumin tidak berhubungan bermakna dengan kejadian enterokolitis pascabedah $(p>0,05)$ sedangkan lama operasi, lama perawatan, dan jenis operasi berhubungan bermakna dengan kejadian enterokolitis.

Hasil analisis dengan melakukan uji regresi logistik ganda menunjukkan bahwa lama operasi merupakan variabel yang paling dominan untuk terjadinya enterokolitis pascabedah (RR=5,79; 95\% Cl:1,15-29,16; $p=0,03$ ) (Tabel 3). Jenis operasi tidak diikutkan dalam model regresi logistik karena berhubungan secara statistik terhadap lama operasi dan lama perawatan sedangkan syarat regresi logistik adalah tidak boleh ada interaksi sesama variabel bebas dan variabel luar. Dalam hal ini, lama operasi dan lama perawatan lebih kuat pengaruhnya terhadap outcome (enterokolitis) sehingga jenis operasi didrop dari analisis regresi logistik (18).

\section{BAHASAN}

Enterokolitis pascabedah merupakan komplikasi paling berbahaya yang ditandai dengan adanya distensi abdomen, diare, muntah, dan demam (19). Hasil penelitian ini menunjukkan bahwa dari 104 subjek penelitian yang dilakukan operasi dengan menggunakan metoda ERPT 
maupun PSNRHD, diperoleh kejadian enterokolitis pascabedah pada 18 subjek (17,3\%) dan menunjukkan adanya perbedaan yang bermakna antara kedua teknik operasi tersebut $(p=0,001)$. Hal ini terjadi karena pada teknik $E R P T$, irisan operasi dilakukan dengan membuka dinding perut bagian depan dan dalam posisi terlentang, mengeluarkan usus besar, dan memotong rektum yang spastik kemudian dilakukan penyambungan usus besar secara endorektal. Sebaliknya, pada teknik $P S N R H D$, irisan operasi adalah melalui irisan intergluteal pada posisi telungkup tanpa mengeluarkan dan memotong rektum. Beberapa penelitian melaporkan angka kejadian enterokolitis pascabedah sebesar $42,3 \%$ dari 78 kasus (19) dan $30 \%$ pada 135 penderita yang dilakukan operasi (14).

Berdasarkan jenis kelamin, diperoleh perbandingan antara laki-laki dan perempuan sebesar $2: 1$. Hasil ini sesuai dengan penelitian lain yang menyatakan bahwa pada penyakit megakolon kongenital, laki-laki lebih dominan dibandingkan perempuan. Demikian juga hasil penelitian di Mesir yang mendapatkan perbandingan 3 : 1 bahkan penelitian di Birmingham mendapatkan perbandingan $4: 1(20)$.

Hasil penelitian ini menunjukkan bahwa kejadian enterokolitis dan albumin tidak menunjukkan perbedaan yang bermakna $(p=0,344)$. Hal ini kemungkinan besar disebabkan oleh adanya faktor-faktor prognostik lain yang dapat mempengaruhi terjadinya enterokolitis pascabedah. Adanya bakteri patogen seperti Clostridium defficile dan pseudomonas, dilatasi kolon yang menyebabkan iskemia, kelainan mukosubstan kolon, kenaikan aktivitas prostaglandin $\mathrm{E} 1$, dan kelainan imunologis akan mempercepat terjadinya enterokolitis pascabedah. Defisiensi sekresi IgA lewat sel mukosa usus akan mempermudah terjadinya invasi bakteri. IgA merupakan pelindung mukosa usus yang cara kerjanya adalah mengikat bakteri sehingga bakteri menjadi tidak aktif. Berbeda dengan hasil penelitian ini, keterkaitan antara tingkat kadar albumin dengan terjadinya komplikasi pascabedah dibuktikan oleh penelitian di India yang menyimpulkan bahwa tingkat kadar albumin praoperasi yang rendah merupakan variabel utama untuk terjadinya komplikasi pascabedah, morbiditas maupun mortalitas pascabedah (21). Penelitian lain di Spanyol juga menunjukkan bahwa terdapat hubungan yang kuat antara tingkat kadar albumin serum dengan komplikasi pascabedah dan lama perawatan di rumah sakit (22).

Berdasarkan umur saat operasi, meskipun hasil analisis menunjukkan tidak bermakna $(p=0,49)$, kemungkinan untuk terjadinya enterokolitis pascabedah pada umur kurang dari satu tahun adalah 0,74 kali dibandingkan umur operasi di atas satu tahun. Hal ini kemungkinan besar disebabkan oleh adanya faktor lain yang mempengaruhi terjadinya enterokolitis pascabedah. Berdasarkan kadar $\mathrm{Hb}$, kemungkinan untuk terjadinya komplikasi akan lebih besar jika kadar $\mathrm{Hb}$ rendah (14). Pada penelitian ini, walaupun hasil analisis menunjukkan tidak bermakna $(p=0,747)$, enterokolitis pascabedah yang terjadi pada subjek dengan kadar $\mathrm{Hb}$ kurang dari atau sama dengan $12 \mathrm{~g} / \mathrm{dl}$ adalah 1,42 kali dibandingkan subjek dengan kadar $\mathrm{Hb}$ lebih dari $12 \mathrm{~g} / \mathrm{dl}$. Hal ini disebabkan adanya kemampuan transportasi oksigen dan faktor-faktor nutrisi yang lebih baik apabila operasi dikerjakan pada kadar $\mathrm{Hb}$ lebih dari $12 \mathrm{~g} / \mathrm{dl}$.

Kemungkinan terjadinya enterokolitis pascabedah pada lama operasi kurang dari atau sama dengan 60 menit adalah 0,22 kali dibanding lama operasi lebih dari 60 menit $(p=0,001)$. Hal ini terjadi karena adanya manipulasi usus besar dalam waktu yang lama sehingga akan mempengaruhi terjadinya infeksi pada mukosa usus besar (3). Berdasarkan lama waktu perawatan, hasil penelitian ini menunjukkan adanya perbedaan yang bermakna $(p=0,032)$, yaitu kejadian enterokolitis pascabedah pada lama waktu perawatan kurang dari atau sama dengan 10 hari adalah 0,26 kali dibandingkan dengan lama perawatan lebih dari 10 hari. Hal ini kemungkinan besar disebabkan oleh paparan bakteri yang cukup lama sehingga dapat mengakibatkan tejadinya infeksi pada mukosa usus besar (3). Namun, hasil analisis multivariat menunjukkan bahwa lama operasi merupakan variabel yang paling dominan untuk terjadinya enterokolitis pascabedah $(p=0,03)$.

\section{SIMPULAN DAN SARAN}

Kadar albumin secara statistik tidak berpengaruh terhadap terjadinya enterokolitis pascabedah penderita penyakit megakolon kongenital (Hirschsprung's disease). Namun, secara klinis perlu dipertimbangkan untuk melakukan operasi dengan kadar albumin lebih dari 3,5 g/dl.

\section{RUJUKAN}

1. Teitelbaum DH, Wulkan ML, Georgeson KE, Langer JC. Hirschsprung's disease. In: Operative pediatric surgery. Philadelphial: Mc-Graw - Hill Professional; 2003.

2. Kartono D. Penyakit Hirschsprung. Jakarta: Sagung Seto; 2004.

3. Ali KAE. Transanal endorectal pull-through for Hirschsprung's disease during the first month of life. Annal Pediatr Surg 2010;6(2):81-8.

4. Estevao-Costa J, Fragoso AC, Campos M, SoaresOliveira M, Carvalho JL. An approach to minimize postoperative enterocolitis in Hirschprung's disease. J Pediatr Surg 2006;41(10):1704-07.

5. Leeuwen KV, Geiger JD, Barnett JL, Coran AG, Teitelbaum $\mathrm{DH}$. Stooling and manometric finding after primary pull-through in Hirschsprung's disease: 
perineal versus abdominal approaches. J Pediatr Surg 2002;37(9):1321-5.

6. El-Sawaf MI, Drongowski RA, Chamberlain JN, Coran AG, Teitelbaum DH. Are the long term results of the transanal pull-through equal to those of the transabdominal pull-through? A comparison of the 2 approaches for Hirschsprung disease. J Pediatr Surg 2007;42(1):41-7.

7. Surana R, Quinn FMJ, Puri P. Evaluation of risk factors in the development of enterocolitis complicating Hirschsprung's disease. Pediatr Surg Int 1994;9(4):234-6.

8. Storey DW. Microbial studies of enterocolitis in Hirschsprung's disease. Ped Surg Int 1994; 9(4):24850.

9. Gibbs J, Cull W, Henderson W, Daley J, Hur K, Khuri FS. Preoperative serum albumin level as a predictor of operative mortality and morbidity: results from the National VA Surgical Risk Study. J Arch Surg 1999;134(1):36-42.

10. Langer JC. Hirschsprung's disease in principles and practice of pediatric surgery. Philadelphia: Lippincott William \& Wilkin; 2005.

11. Lemeshow S, Hosmer Jr DW, Klar J, Lwanga SK. Besar sampel dalam penelitian kesehatan. Pramono D. 1997 (Alih bahasa). Yogyakarta: UGM Press; 1997.

12. Niedringhaus L. Hypovolemic shock in shock comprehensive nursing management. London: Mosby Company; 1983.
13. Teitelbaum DH, Cilley RE, Sherman NJ, Biiss D, Uitvlugt ND, Renaud EJ, Kirstioglu I, Bengston T, Coran AG. A decade of experience with the primary pull-through for Hirschsprung disease in the newborn period: a multicenter analysis of outcomes. Ann Surg 2000;232(3):372-80.

14. Sieber WK. Hirschprung's disease in pediatric surgery. London: Year Book Medical Publisher; 1986.

15. Guzzetta PC, Anderson KD, Altman RP, Newman KD, Eichelberger MR, Randolp J. Hirschsprung's disease in principles of surgery. 5th ed. New York: McGraw-Hill Information Services Company; 1988.

16. Betts EK, Downes JJ. Anesthesia in pediatric surgery. London: Year Book Medical Publisher INC; 1986.

17. Soper RT. Abdominal pain in synopsis of pediatric surgery. Stuttgart: Georg Thieme Publishers; 1975.

18. Bernard R. Fundamentals of biostatistik. 2nd ed. Boston: Duxbury Press; 1986

19. Holschneider A, Ure BM. Hirschsprung's disease in pediatric surgery. Philadelphia: Elsevier Saunders; 2005.

20. Haricharan RN, Georgeson KE. Hirschsprung disease. Semin Pediatr Surg 2008;17(4):266-75.

21. Agarwala S, Bathnagar V, Mitra DK. Long-term followup of Hirschsprung's disease: review of early and late complications. Indian Ped 1996;33(5):382-6.

22. Rodriguez DM, Cuadros MM, Ortega GA, Gallego MG, Ortiz MM, Gonzales MAM, Arenas SM. Cholesterol and serum albumin levels as predictor of cross infection, death, and length of hospital stay. Arch Surg 2002;137(7):805-12. 